\title{
Lipid composition and food quality of some freshwater phytoplankton for cladoceran zooplankters
}

\author{
Gunnel Ahlgren, Lisa Lundstedt, Michael Brett and Curt Forsberg \\ Institute of Limnology, Box 557, S-751 22 Uppsala, Sweden
}

\begin{abstract}
The nutritional value of several planktonic algae was tested by means of feeding trials with three cladoceran zooplankters. The algae were monocultures and included two blue-greens, four greens and four flagellates with a size range of 5-48 $\mu \mathrm{m}$. The specific growth rates of the zooplankters were chosen as the measure of the nutritional value of the algae. The three cladocerans showed large differences in growth rate in the different algae, but the two cryptomonads were without doubt best suited as food for all. The fatty acid composition for the cryptomonads were different from the other algae. They contained high percentages of the polyunsaturated fatty acids 20:5 33 (EPA) and 22:6 33 (DHA), which also are common in fish. It is suggested that the lipid composition is a probable factor determining the nutritional quality of the algae.
\end{abstract}

\section{Introduction}

Research on the nutritional requirements of zooplankton started in the 1950s and was originally oriented towards marine species (Corner and Cowey, 1968). It was established that certain algal species (e.g. some diatoms, cryptomonades and flagellates) were 'good' feed while others (some green and blue-green algae) were characterized as 'poor' feed (e.g. De Pauw and Pruder, 1986). However, the exact reasons why certain algal species promote better growth and reproduction than others are still poorly known.

There are many aspects which must be considered when determining the nutritional quality of algae for zooplankton, that is acceptable size range, digestible cell wall, non-toxicity and proper chemical composition. A great deal of research has been carried out on the first three aspects (e.g. Burns, 1968; Porter, 1973; Lampert et al., 1986; Skogstad et al., 1987; Burns, 1987; Lampert, 1987). A variety of algae of suitable size may be ingested by a zooplankton species, but only a limited number of algal species will be nutritionally adequate and therefore of importance to zooplankton (Stemberger, 1981).

During early studies of zooplankton nutrition a great interest was paid to the algal amino acid composition, but conflicting results were reported from different studies (e.g. Parsons et al., 1961; Corner and Cowey, 1968). Recently, an increasing interest has been put into the lipid fraction and particularly the content of unsaturated fatty acids of $\omega 6$ and $\omega 3$ type (two families of the polyunsaturated fatty acids, differing by the position of the first double bond in the carbon chain). Interest in fatty acid composition originates to a large degree from the growing interest in aquaculture, which requires nutrient-rich microalgae and/or zooplankton for the diets of larval stages of commercially important fish and shellfish. There is a general lack of knowledge on the nutritional requirements of these organisms, and it is highly probable that the requirements differ between species (Taub, 1970; De Pauw and Pruder, 1986). Natural food seems to be essential for many of these sensitive organisms, and it has been 
suggested that the composition of lipids in the diet may be more important than that of the protein or carbohydrate components (De Pauw and Pruder, 1986).

The objective of this study was to determine the utility of several freshwater algae as food for three cladoceran zooplankters with special interest paid to the unsaturated fatty acids. We suggest that the lipid composition is a possible factor determining the nutritional quality of the algae.

\section{Materials and methods}

The phytoplankton were chosen to cover a common size range and species composition representative of meso- to eutrophic temperate lakes (Table I). The synthetic medium L16 (Lindström, 1983a) was used for all the experiments which were carried out at a temperature of $15^{\circ} \mathrm{C}$ and a $14 / 10 \mathrm{~h}$ light/dark cycle. The phytoplankton cultures used were not axenic, but it can hardly give any decisive influence to the main results (see further under Discussion). Microcystis and Scenedesmus, which are generally colonial in lake plankton, were largely single celled in the monocultures used.

The zooplankter Chydorus sphaericus $(0.3 \mathrm{~mm})$ was taken from a laboratory monoculture, while Eubosmina longispina $(0.5 \mathrm{~mm})$ and Daphnia longispina $(1.2 \mathrm{~mm})$ were isolated from Lake Vallentunasjön just before the start of the experiments. The zooplankters were preconditioned by keeping them in the different food types for 10 days. Since only growth experiments can provide information on the ultimate utilization of a certain food, we chose the specific growth rate of the zooplankters as a measure of the nutritional value of the algae.

The experiments were carried out in $75 \mathrm{ml}$ Erlenmeyer flasks. At the start of the experiments 10 or 20 individuals of the zooplankters were added to each

Table 1. Size characteristics of the food algae

\begin{tabular}{|c|c|c|c|c|}
\hline & \multicolumn{2}{|c|}{ Length } & \multicolumn{2}{|l|}{ Width } \\
\hline & $\overline{\mu m}$ & $(\mathrm{CV})$ & $\mu \mathrm{m}$ & $(\mathrm{CV})$ \\
\hline \multicolumn{5}{|l|}{ Blue-greens } \\
\hline $\begin{array}{l}\text { Microcystis aeruginosa Kütz. } \\
\text { Oscillatoria agardhii Gom. }\end{array}$ & $\begin{array}{ll}4.8 \\
557\end{array}$ & $\begin{array}{l}(29) \\
(24)\end{array}$ & - & $(0)$ \\
\hline \multicolumn{5}{|l|}{ Greens } \\
\hline Chlamydomonas sp. & 10.1 & (22) & 7.8 & (24) \\
\hline Chlorella homosphaera Skuja & 4.6 & (17) & - & \\
\hline Scenedesmus acutus Meyen & 13.0 & (10) & 5.0 & (16) \\
\hline Scenedesmus quadricauda Turp. & 11.5 & (13) & 5.9 & (20) \\
\hline cells with spines & 19.7 & (15) & 11.5 & (19) \\
\hline \multicolumn{5}{|l|}{ Flagellates } \\
\hline Chromulina chinophila Stain & 5.5 & (9) & - & \\
\hline Cryptomonas sp. & 17.3 & (9) & 9.1 & (11) \\
\hline Rhodomonas lacustris Pasch. \& Ruttn. & 11.0 & (15) & 6.4 & (16) \\
\hline Peridinium cinctum (O.F.Müll.) Ehr. & 48.0 & (15) & 43.7 & (11) \\
\hline
\end{tabular}

$C V=$ coefficient of variation, i.e., SD in \% of mean.

$n=10$. 
algal monoculture. The growth experiments lasted 10 days and had six replicates. In those cases where survival during the preconditioning period was poor, fewer replicates were employed (cf. Table II). In order to avoid food limitation additional algae were added to those assays where a risk for overgrazing was apparent. Supposing exponential growth the instantaneous growth rates $(r)$ of the zooplankters were calculated from the means of change in number of the individuals according to the following equation (e.g. Edmondson and Winberg, 1971, p. 165):

$$
r=\left(\ln N_{\mathrm{t}}-\ln N_{0}\right) / t
$$

where $\mathrm{N}_{0}=$ number of individuals at day 0

$N_{\mathrm{t}}=$ number of individuals at day 10

$t=$ time (10 days)

The different algae were grouped in three size groups $(5,11$ and $\geqslant 17 \mu \mathrm{m})$ when presenting the estimated growth rates of the zooplankters (Figure 1).

The fatty acid composition of the algae was analysed by means of a HewlettPackard GLC-system on chloroform-methanol extracts of freeze-dried algae (Boberg et al., 1985).

\section{Results}

The three cladoceran zooplankters showed large differences in growth in the different phytoplankton cultures (Table II and Figure 1). When given the bluegreens, only Chydorus was able to increase in some of the replicates in Oscillatoria. Eubosmina could not even survive for 20 days (the conditioning and

Table II. Means of number of zooplankters $(N)$, standard deviation (SD) and number of replicates $(n)$ after 10 days in the different algal cultures. The number of individuals at the start of the experiments was 10 in all cases. $\dagger=$ all died

\begin{tabular}{|c|c|c|c|c|c|c|c|c|c|}
\hline \multirow[t]{2}{*}{ Food algae } & \multicolumn{3}{|c|}{ Chydorus } & \multicolumn{3}{|c|}{ Eubosmina } & \multicolumn{3}{|c|}{ Daphnia } \\
\hline & $N$ & SD & $n$ & $N$ & SD & $n$ & $N$ & SD & $n$ \\
\hline \multicolumn{10}{|l|}{ Blue-greens } \\
\hline Microcystis & 3.4 & 0.2 & 6 & 0.3 & 0.0 & 4 & 2.9 & 1.0 & 5 \\
\hline Oscillatoria & 11.3 & 2.3 & 6 & $\dagger$ & - & 5 & 0.8 & 0.5 & 4 \\
\hline \multicolumn{10}{|l|}{ Greens } \\
\hline Chlamydomonas & 21.2 & 2.1 & 6 & 0.9 & 0.6 & 5 & 16.8 & 2.2 & 6 \\
\hline Chlorella & 19.2 & 2.9 & 6 & 2.1 & 0.8 & 6 & 3.6 & 1.3 & 5 \\
\hline Scenedesmus acutus & 20.7 & 2.4 & 6 & $t$ & - & 0 & 26.2 & 4.4 & 6 \\
\hline Scenedesmus quadricauda & 4.9 & 2.1 & 6 & 0.6 & 0.6 & 4 & 3.0 & 1.2 & 4 \\
\hline \multicolumn{10}{|l|}{ Flagellates } \\
\hline Chromulina & 17.0 & 1.8 & 6 & 0.4 & 0.3 & 4 & 3.8 & 1.9 & 5 \\
\hline Cyyptomonas & 24.8 & 1.5 & 6 & 15.1 & 4.9 & 5 & 115 & 16 & 5 \\
\hline Rhodomonas & 30.3 & 1.5 & 6 & 17.7 & 9.0 & 6 & 146 & 12 & 6 \\
\hline Peridinium & - & - & - & $\dagger$ & - & 3 & 2.8 & 0.5 & 4 \\
\hline
\end{tabular}



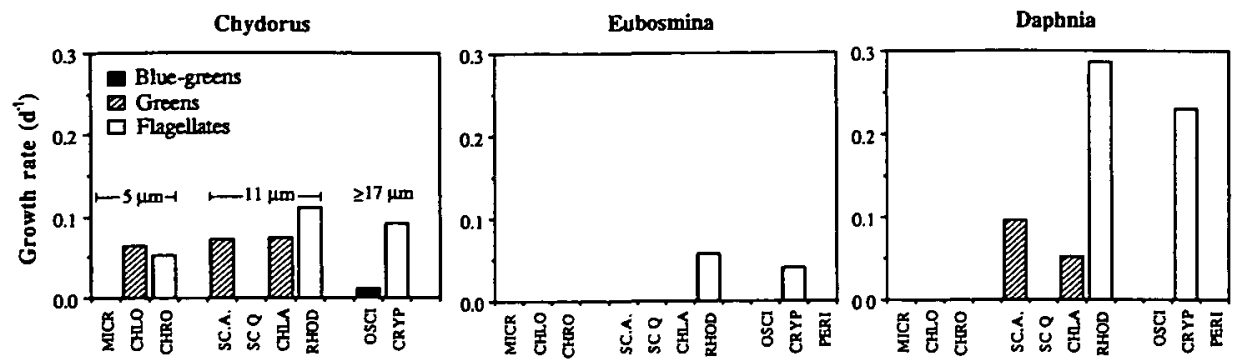

Fig. 1. Estimated growth rates of the three cladocerans fed the different freshwater algae. The algae are grouped in three size groups which are indicated in the figure.

experimental period) in the two blue-greens. Concerning the four green algae (striated bars in Figure 1) all but Scenedesmus quadricauda were good food for Chydorus whereas Daphnia increased only on Scenedesmus acutus and Clamydomonas. Eubosmina was able to survive in all greens except S.acutus, but did not show positive population growth (Table II). Scenedesmus quadricauda did not support growth of any of the cladocerans. The two cryptomonads, Rhodomonas minuta and Cryptomonas sp., despite different sizes, were with no doubt best suited as food for all three cladocerans (Figure 1).

Thus, Chydorus survived in all experiments and did very well in Rhodomonas, and Cryptomonas, and rather well in Chlamydomonas, S.acutus, Chlorella and Chromulina. In contrast, Eubosmina did not grow in most of the experiments and in three of them (Oscillatoria, S.acutus and Peridinium) they died in all replicates. Eubosmina showed a positive growth only in the Cryptomonas and Rhodomonas cultures. Daphnia also survived in all cultures but showed more variation between the algal species than did Chydorus (Table II). Daphnia had a positive growth rate in four of the algal cultures, that is Rhodomonas, Cryptomonas, S.acutus and Chlamydomonas (Figure 1).

The fatty acid composition varied a great deal between the algal species (Table III). Only the flagellates contained long-chained polyunsaturated fatty acids with 20 or 22 carbon. More than $50 \%$ of the fatty acids in Cryptomonas and Rhodomonas consisted of the two $\omega 3$ acids EPA (eicosapentaenoic acid, 20:5 $\omega 3$ ) and DHA (docosahexaenoic acid, 22:6w3). All the greens and Oscillatoria contained instead more of a shorter $\omega 3$-acid, $18: 3 \omega 3$ ( $\alpha$-linolenic acid).

\section{Discussion}

There are several reports of blue-greens being poorly utilized as food (e.g. Arnold, 1971; Lampert, 1987). Daphnia was found to decrease in size and embryo production when Oscillatoria became numerous, which could depend on Oscillatoria filaments interfering with the feeding process, and/or a chemical inhibition (Infante and Abella, 1985). Blue-greens are known to produce toxic metabolites, and Porter and Orcutt (1980) showed in their study of Daphnia magna that a toxin-producing strain of Anabaena flos-aquae promoted indivi- 
dual growth but reduced survivorship when ingested. When investigating the gut contents of Daphnia galeata and D.cuculata, G.-Toth et al. (1987) noticed that although the guts contained blue-greens, it appeared that these were not digested. According to De Bernardi et al. (1981) the size of the colonies of Microcystis is the major reason for their unsuitability as food rather than their undigestibility. They suggested that Microcystis can be efficiently utilized if the algal colonies are small. Microcystis was single celled in the present study so that explanation is inconsistent with our results. A more general explanation why the blue-greens so often are found to be of poor quality can be that they simply are nutritionally incomplete.

Studies with Daphnia and ciliates have shown low growth rates and reproductive values when fed with the green alga Chlorella (Infante and Litt, 1985; Skogstad et al., 1987). The reproduction by Daphnia pulex was much lower than normal when fed Chlorella pyrenoidos and Chlamydomonas reinhardhii (Taub and Dollar, 1968). Many eggs showed an abnormal development or did not develop at all, which can be interpreted as lack of essential substances. There are also examples where green algae (Scenedesmus, Ankistrodesmus and Chlorella) have given good growth for Daphnia and Keratella (Rees and Oldfather, 1980; Lindström, 1983b, Lundstedt and Brett, unpublished). Chlamydomonas has been shown to be suitable food for ciliates (Skogstad et al., 1987) and for D.magna (Porter and Orcutt, 1980).

Among the green algae there are, thus, more variable results; related algal species or even the same species could be characterized as 'poor' or 'good' feed in different experiments. It has, however, been demonstrated very early that the nutritional value varies with the growth condition of the algae, for example, Ryther (1954) and McMahon and Rigler (1965) showed that old slow growing Chlorella vulgaris was of lower quality as food for D. magna than fast growing algae. Marine species of Chlorella were more valuable as food for rotifers than freshwater species of this genus (Watanabe et al., 1983). Different growth conditions of the same species can be an explanation to many conflicting results in determining their food value for herbivores.

There are many examples in the literature showing the grazing habits of daphnids on cryptomonads (especially Rhodomonas) (see the review of Klaveness, 1988). The cryptomonads were also shown to be important food for other zooplankters for example Rotifera and ciliates (Stemberger, 1981; May, 1987; Skogstad et al., 1987). Infante and Litt (1985) found in their study of Daphnia pulicaria and D.thorata that Cryptomonas was the best food for both and suggested that the reasons for that could be their solitary condition, form and size, despite relatively low amounts of carbon and nitrogen. Their favourable size and/or form should, thus, compensate for their low amounts of nutrients. The fact that these flagellates are motile and remain in suspension, could also make it easier for the filtering zooplankters to ingest the cells (May, 1987).

On the other hand, the fatty acid composition for the two cryptomonads is different from the other algae (Table III). They contained high percentages of the long-chained polyunsaturated fatty acids EPA and DHA, which also are 


\section{G.Ahlgren et al.}

Oownloaded from http:/plankt 3 .

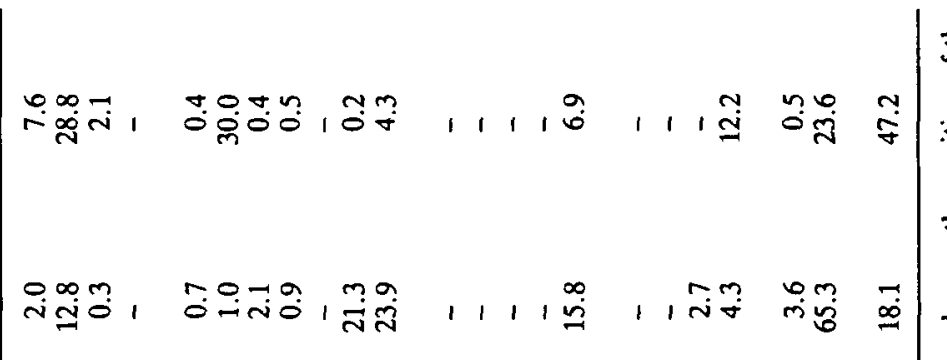

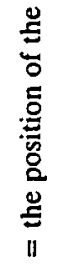

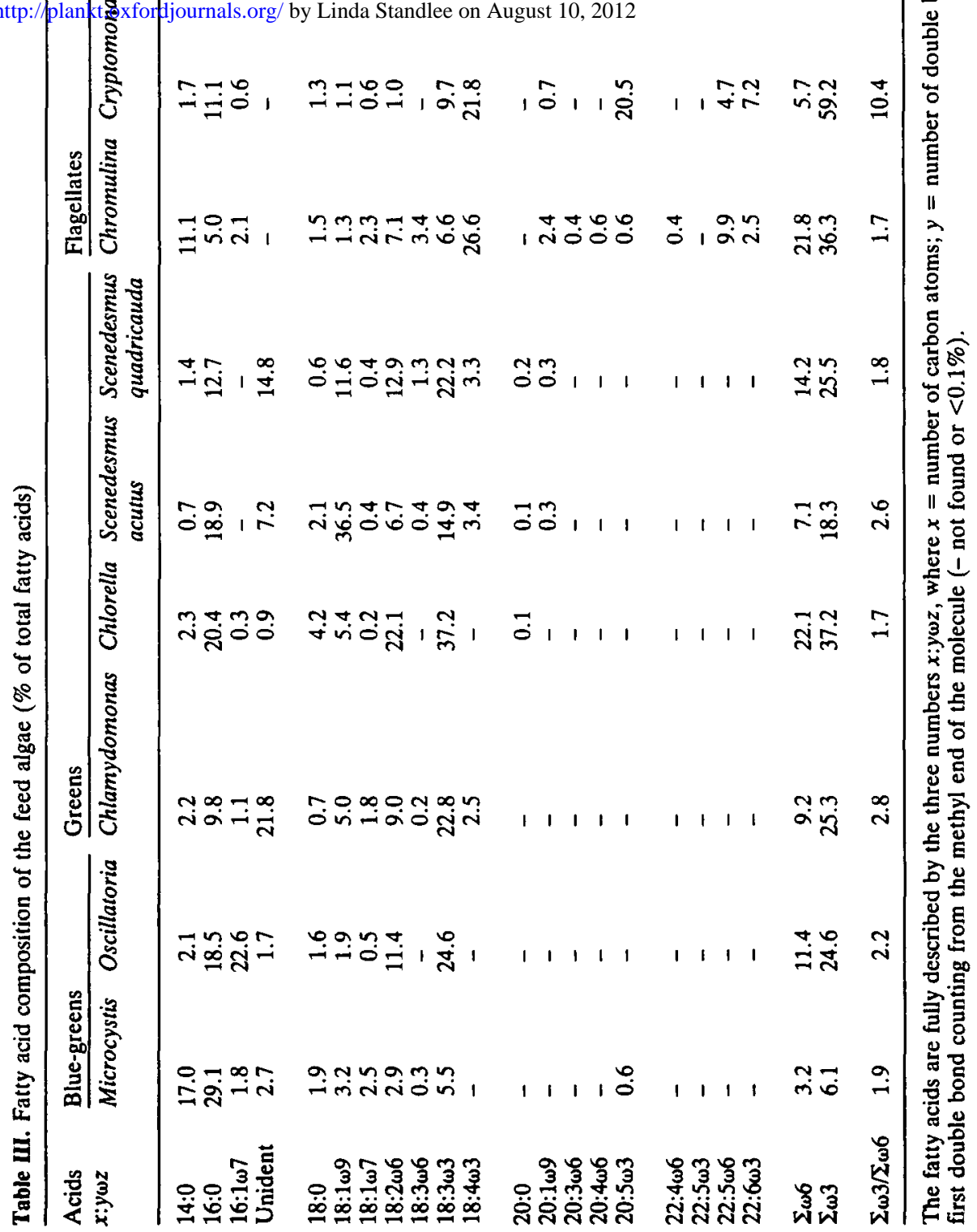


common in fish and shellfish. Chemical composition of the food particles is probably more important than other factors, for example, cell size or digestibility of cell walls, in determining population growth rates. Bern (1987, 1990) found that the optimum cell classes of Chydorus sphaericus was $\sim 10 \mu \mathrm{m}$, and the selectivity coefficient was halved for particles of $19 \mu \mathrm{m}$. In our experiments Chydorus showed nearly the same growth rates when fed the larger Cryptomonas as when fed Rhodomonas (Figure 1). Also the other two cladocerans showed the highest growth rates when fed the two cryptomonads, independent of cell size (Figure 1). Concerning digestibility of cell walls, no difference was found between S.acutus and the softwalled Chlamydomonas as food for Chydorus, and when fed Daphnia the hardwalled Scenedesmus gave, in fact, a higher growth rate than Chlamydomonas. In the smallest cell class, Chydorus grew with about the same rate on Chlorella and the softwalled Chromulina, but the softwalled Microcystis-cells could not support growth of any of the cladocerans. If algal particles are nutritionally inadequate, it is irrelevant that they are of a suitable size. Bacteria are considered to contain no long-chained polyunsaturated fatty acids (Kenyon, 1972; Volkman et al., 1989), so the bacteria in the non-axenic cultures could hardly influence the main results or the conclusions.

It has been found that microalgae determine the quality of the marine rotifer Brachionus plicatus, which is frequently used as a food organism in industrial hatcheries (Watanabe et al., 1983). That is thought to be due to the essential fatty acids which are only synthesized by algae (De Pauw and Pruder, 1986; Volkman et al., 1989). The dietary value of rotifers for fish has been related to the content of highly unsaturated fatty acids of the w3-type (Watanabe et al., 1983). It is probable that these compounds also are essential for the two larger cladocerans, whereas Chydorus can use the shorter $18 \omega 3$ acids in the green algae as well as in Oscillatoria and Chromulina. As a measure of the effects of cell size (Table I) against the fatty acids of $\omega 3$ - and $\omega 6$-type (Table III) of the food algae on the growth response of the cladocerans (Table II) the Spearman's rank correlation coefficients are calculated (Table IV). The coefficients are highest

Table IV. Effects of cell sizes, the sum of $\omega 3$-acids and the sum of $\omega 3+\omega 6$-acids of the food algae on the growth response of the cladocerans measured as Spearman's correlation coefficients $(p)$

\begin{tabular}{lllll}
\hline Cladoceran & Variable & $\rho$ & $n$ & Significance \\
\hline Chydorus & Size & 0.49 & 9 & 0.185 \\
& $\sum \omega 3$ & 0.65 & 9 & 0.058 \\
& $\sum \omega 3+\omega 6$ & 0.58 & 9 & 0.099 \\
Eubosmina & Size & -0.07 & 10 & 0.853 \\
& $\sum \omega 3$ & 0.87 & 10 & 0.001 \\
& $\sum \omega 3+\omega 6$ & 0.80 & 10 & 0.005 \\
Daphnia & Size & 0.30 & 10 & 0.403 \\
& $\sum \omega 3$ & 0.59 & 10 & 0.074 \\
& $\sum \omega 3+\omega 6$ & 0.59 & 10 & 0.074 \\
\hline
\end{tabular}




\section{G.Ahlgren et al.}

for the fatty acids for all cladocerans. The probability is between 0.1 and $10 \%$ that the growth response of the zooplankters is independent on the fatty acids, whereas the probability is between 19 and $85 \%$ that the growth response is independent of the cell size. In this test the diameter of the Oscillatoria filaments was chosen as the size variable. Using the length of the filaments as size variable gave a $\rho$ of only 0.2 for Chydorus, which is probably misleading. (Chydorus could, in fact, eat those soft filaments.)

The reason why Chydorus could not utilize S.quadricauda cannot be explained by fatty acid composition, which was very similar to that of the other three green algae. Harder cell walls and resisting spines may be the reason. Microcystis, which also was 'poor' food, contained the lowest per cent of $\omega 3$ acids of all species (Table III). It is interesting to note that Microcystis contained traces of EPA, which may be an explanation for the fact that Daphnia and Chydorus showed positive growth on Microcystis in another series of experiments (Lundstedt and Brett, unpublished). Peridinium also contained some EPA and DHA fatty acids. The difficulties for Eubosmina and Daphnia to increase or even survive in Peridinium could depend on the size $(48 \mu \mathrm{m})$ and the hard cell wall of the algae. According to Burns' (1968) relationship between carapace length and bead particles ingested, the cladocerans must be at least $1.5 \mathrm{~mm}$ to be able to eat particles of $48 \mu \mathrm{m}$. Bern (1990) has recently demonstrated that D.cuculata $(0.75 \mathrm{~mm})$ did not select particles $>38 \mu \mathrm{m}$. Peridinium cinctum has been shown to be an excellent food source for the large rotifer Asplanchna (Brett, unpublished).

\section{Conclusions}

The two cryptomonads, which contained high percentages of long-chained polyunsaturated fatty acids of $\omega 3$-type, were the best food for all cladocerans, in spite of the fact that they belonged to different size classes. We suggest that the lipid composition is a probable factor determining the nutritional quality of the algae.

\section{Acknowledgements}

We wish to thank S.Tengblad, I.-B.Gustavsson and M.Boberg, Department of Geriatrics, Uppsala, for help with the fatty acid analyses. We also thank L.Bern, Institute of Limnology, Uppsala, for valuable suggestions on the manuscript.

\section{References}

Arnold,D.E. (1971) Ingestion, assimilation, survival, and reproduction by Daphnia pulex fed seven species of blue-green algae. Limnol. Oceanogr., 16, 906-920.

Bern,L. (1987) Zooplankton grazing on [methyl-3H]thymidine-labelled natural particle assemblages: determination of filtering rates and food selectivity. Freshwater Biol., 17, 151-159.

Bern,L. (1990) Food choice in some freshwater, crustacean zooplankters. Acta Universitatis Upsaliensis, (Summaries of Uppsala Dissertations from the Faculty of Science), 245, 1-15. 
Boberg,M., Croon,L.B., Gustafsson,I.-B. and Vessby,B. (1985) Platelet fatty acid composition in relation to fatty acid composition in plasma and to serum lipoprotein lipids in healthy subjects with special reference to the linoleic acid pathways. Clin. Sci., 68, 581-587.

Burns,C.W. (1968) The relationship between the body size of filter-feeding Cladocera and the maximum size of particle ingestion. Limnol. Oceanogr., 13, 675-678.

Burns,C.W. (1987) Insights into zooplankton-cyanobacteria interactions derived from enclosure studies. N.Z. J. Mar. Freshwater Res., 21, 477-482.

Corner,E.D.S. and Coway,C.B. (1968) Biochemical studies on the production of marine zooplankton. Biol. Rev., 43, 393-426.

De Bernardi,R., Giussani,R.G. and Pedretti,E.L. (1981) The significance of blue-green algae as food for filtering zooplankton: experimental studies on Daphnia spp. fed by Microcystis aeruginosa. Verh. Int. Verein. Limnol., 21, 477-483.

De Pauw,N. and Pruder,G. (1986) Use and production as food in aquaculture: practice, problems and research needs. In Bilio,M., Rosenthal,H. and Sindermann,C.J. (eds), Realism in Aquaculture: Achievements, Constraints, Perspectives. European Aquaculture Society, Bredene, Belgium, pp. 77-106.

Edmondson,T. and Winberg,G.G. (eds) (1971) A Manual on Methods for the Assessment of Secondary Productivity in Fresh Waters. IBP Handbook No 17. Blackwell Scientific Publications, Oxford.

G.-Tóth,L., Zankai,N.P. and Messner,O.M. (1987) Alga consumption of four dominant planktonic crustaceans in Lake Balaton (Hungary). Hydrobiologia, 145, 323-332.

Infante,A. and Abella,S.E.B. (1985) Inhibition of Daphnia by Oscillatoria in Lake Washington. Limnol. Oceanogr., 30, 1046-1052.

Infante,A. and Litt,A.H. (1985) Differences between two species of Daphnia in the use of species of alga in Lake Washington. Limnol. Oceanogr., 30, 1053-1059.

Kenyon,C.N. (1972) Fatty acid composition of unicellular strains of blue-green algae. J. Bacteriol, $109,827-834$.

Klaveness,D. (1988) Ecology of fresh Chryptomonadida: a first review. In Sandgren,C.D. (ed.), Growth and Reproductive Strategies of Freshwater Phytoplankton. Cambridge University Press, Cambridge, pp. 105-133.

Lampert,W. (1987) Laboratory studies on zooplankton-cyanobacteria interactions. N.Z. J. Mar. Freshwater Res., 21, 483-490.

Lampert,W., Fleckner,W., Rai,H. and Taylor,B.E. (1986) Phytoplankton control by grazing zooplankton: A study on the spring clear-water phase. Limnol. Oceanogr., 31, 478-490.

Lindström,K. (1983a) Selenium as a growth factor for plankton algae in laboratory experiments and in some Swedish lakes. Hydrobiologia, 101, 35-47.

Lindström,K. (1983b) Changes in growth and size of Keratella cochlearis (Gosse) in relation to some environmental factors in cultures. Hydrobiologia, 104, 325-328.

May,L. (1987) Culturing freshwater, planktonic rotifers on Rhodomonas minuta var. nannoplanctica Skuja and Stichococcus bacillaris Nägeli. J. Plankton Res., 9, 1217-1223.

McMahon,J.W. and Rigler,F.H. (1965) Feeding rate of Daphnia magna Straus in different foods labeled with radioactive phosphorus. Limnol. Oceanogr., 10, 105-113.

Parsons,T.R., Stephens,K. and Strickland,J.D.H. (1961) On the chemical composition of eleven species of marine phytoplankters. J. Fish. Res. Bd Can., 18, 1001-1016.

Porter,K.G. (1973) Selective grazing and differential digestion of algae by zooplankton. Nature, 244, 179-180.

Porter,K.G. and Orcutt,J.D.,Jr (1980) Nutritional adequacy, manageability, and toxicity as factors that determine the food quality of green and blue-green algae for Daphnia. In Keerfoot,C. (ed.), Evolution and Ecology of Zooplankıon Communities. University Press of New England, Hanover, pp. 268-281.

Rees,J. and Oldfather,J.M. (1980) Small-scale mass cultures of Daphnia magna Straus. Proc. World Maricult. Soc., 11, 202-210.

Ryther,J.H. (1954) Inhibitory effects of phytoplankton upon the feeding of Daphnia magna with reference to growth, reproduction and survival. Ecology, 35, 522-533.

Skogstad,A., Granskog,L. and Klaveness,D. (1987) Growth of freshwater ciliates offered planktonic algae as food. J. Plankton Res., 9, 503-512.

Stemberger,R.S. (1981) A general approach to the culture of planktonic rotifers. Can. J. Fish. Aquat. Sci., 38, 721-724.

Taub,F.B. (1970) Algal culture as a source of feed. In Avault,J.W.,Jr, Boudreaux,E. and Jaspers,E. (eds), Proceedings of the First Annual Workshop World Mariculture Sociery. Louisiana State University, Baton Rouge, pp. 101-117. 


\section{G.Ahlgren et al.}

Taub,F.B. and Dollar,A.M. (1968) The nutritional inadequacy of Chlorella and Chlamydomonas as food for Daphnia pulex. Limnol. Oceanogr., 13, 607-617.

Volkman,J.K., Jeffrey,S.W., Nichols,P.D., Rogers,G.I. and Garland,C.D. (1989) Fatty acid and lipid composition of 10 species of microalgae used in mariculture. J. Exp. Mar. Biol. Ecol., 128, 219-240.

Watanabe,T., Kitajima,C. and Fujita,S. (1983) Nutritional values of live organisms used in Japan for mass propagation of fish: a review. Aquaculture, 34, 115-143.

Received on June 19, 1989; accepted on March 27, 1990 